\title{
Penempatan Kerja Dan Rotasi Kerja Vs Kinerja Karyawan
}

\author{
Oleh: \\ Didi Suarni \\ Rika Yusminah
}

Sekolah Tinggi Ekonomi Syariah (STES) Islamic Village Jln Raya Islamic Village Kelapa Dua Tangerang 15810

\begin{abstract}
Abstrak: Penelitian ini berusaha untuk meneliti apakah penempatan kerja dan rotasi kerja berpengaruh positif terhadap kinerja karyawan pada PT. Bank BNI Syariah Kantor Cabang Tangerang. Penelitian ini menggunakan metode deskriptif kuantitatif, dengan menggunakan sampel sebanyak 30 responden, pengumpulan data menggunakan angket kuesioner dan dianalisis menggunakan regresi linear berganda, dimana sebelumnya dilakukan uji validitas dan uji reliabilitas terlebih dahulu. Pada uji parsial, hasil penelitian ini menunjukkan bahwa variabel penempatan kerja tidak berpengaruh positif pada variabel kinerja karyawan, sedangkan variabel rotasi kerja berpengaruh positif dan signifikan terhadap variabel kinerja karyawan. Pada uji simultan variabel-variabel independen secara signifikan menpengaruhi variabel dependen.

Kata Kunci: Penempatan Kerja, Rotasi Kerja, Kinerja Karyawan.
\end{abstract}

\section{Pendahuluan}

Saat ini pertumbuhan bank syariah di Indonesia sudah menjamur. Hingga Januari 2016, industri perbankan syariah memiliki jaringan sebanyak 12 Bank Umum Syariah (BUS), 23 Unit Usaha Syariah (UUS), dan 155 Bank Pembiayaan Rakyat Syariah (BPRS). Dengan total jaringan kantor mencapai 2747 kantor yang tersebar hampir di seluruh nusantara.(Syariah finance,2016).

Akan tetapi, perkembangan industri perbankan syariah saat ini, tidak diimbangi dengan kesiapan sumberdaya manusia yang memadai. Hasil riset yang dilakukan oleh Fakultas Ekonomi Universitas Indonesia (FEUI) seperti dikutip oleh Syaparuddin (2014:355), menunjukkan bahwa lebih dari 90\% sumberdaya manusia bank syariah saat ini tidak memiliki latar belakang pendidikan ekonomi syariah.

Kebutuhan perbankan syariah terhadap SDM yang berkualiatas terus meningkat. Dengan asumsi pertumbuhan perbankan syariah sebesar 20\% pertahun, maka rata-rata kebutuhan terhadap SDM 
perbankan syariah sekitar 15.000 orang pertahun. Padahal saat ini perguruan tinggi di Indonesia baru menghasilkan lulusan sekitar 3000 orang pertahun di bidang ekonomi dan keuangan syariah. Artinya tenaga profesional perbankan syariah masih diisi oleh SDM dengan dasar keilmuan di bidang lain (Harisman,2016).

Sumberdaya manusia merupakan salah satu asset yang sangat berharga dalam mewujudkan tujuan perusahaan oleh karena itu perusahaan harus selalu menjaga kualitas sumberdaya manusia yang dimiliki agar perusahaan dapat tetap memberikan manfaat bagi pihak lain.

Kualitas sumberdaya ini tergantung pada penempatan kerja, dimana penempatan kerja diharapkan mampu mengoptimalkan sumberdaya manusia yang dimiliki, sesuai dengan tujuan perusahaan. Dalam penempatan pegawai Rasulullah S.A.W telah mengajarkan tentang bagaimana menempatkan seseorang sesuai kemampuannya, the right man in the right place.

Selain penempatan yang tepat, keahlian juga merupakan hal yang sangat penting dalam meningkatkan kinerja karyawan. Bahkan dalam sebuah hadis Rasulullah S.A.W bersabda:

"Apabila sebuah urusan diserahkan bukan pada ahlinya maka tunggulah saat kehancurannya." (HR. Bukhari).

Dalam bekerja, banyak faktor yang dapat menyebabkan kinerja karyawan menurun. Salah satu faktor yaitu: karena karyawan terusmenerus melakukan pekerjaan yang sama dari waktu ke waktu, sehingga akhirnya akan merasa bosan dan jenuh dalam bekerja. Kebosanan dan kejenuhan itu akan menjebak karyawan tersebut pada rutinitas dan situasi kerja yang monoton, dan pada akhirnya kinerja karyawan menurun.

Oleh karena itu diperlukan cara untuk mengatasi kejenuhan tersebut sehingga karyawan dapat termotivasi untuk tetap meningkatkan kinerja nya. Salah satu cara yang dapat dilakukan dalam upaya peningkatan kinerja adalah perusahaan melakukan kegiatan rotasi kerja dalam beberapa waktu.

Menurut Kasmir (2016:143) Rotasi atau transfer antar bagian merupakan metode pengembangan karyawan yang sudah menempati suatu bagian terlalu lama, tujuannya adalah agar karyawan tidak merasa jenuh dengan pekerjaan yang berada disatu tempat. Selain itu, rotasi dilakukan dalam rangka promosi karyawan tersebut kedepan. Biasanya setiap perusahaan memiliki kebijakan-kebijakan sendiri dalam penerapan waktu rotasi pekerjaan. Ada yang berkala (mingguan,bulanan,tahunan) dan tidak berkala. 


\section{Penempatan Kerja}

Menurut Kasmir (2016: 13) Penempatan merupakan proses menempatkan orang-orang pada tugas atau tempat yang telah ditetapkan sesuai dengan persyaratan yang telah ditetapkan sebelumnya. Setelah diterima menjadi calon karyawan dengan proses yang benar, maka selanjutnya karyawan akan akan langsung ditempatkan atau diperkerjakan terutama bagi karyawan yang dibutuhkan segera.

Sumber penempatan calon karyawan berasal dari sumber internal perusahaan dan sumber eksternal perusahaan. Karyawan dari sumber internal perusahaan diperoleh dengan adanya program promosi, demosi dan transfer (rotasi jabatan). Sumber eksternal berasal dari sumber luar perusahaan.

Dalam penempatan karyawan, Rasulullah S.A.W, telah mengajarkan tentang bagaimana menempatkan seseorang sesuai dengan kemampuan yang dimiliki, the right man in the right place. Rasulullah tidak pernah menjadikan Umar Ibnul Khattab sebagai panglima perang karena memang beliau diarahkan untuk menjadi negarawan. Begitu pula Abu Bakar Ash-Shiddiq, beliau tidak pernah menjabat sebagai pemimpin perang karena memang diarahkan untuk menjadi negarawan. Dan pada saat seorang sahabat nabi, Abu Dzar Al-Ghifari meminta jabatan kepada Rasulullah pada saat teman-temannya sudah diangkat menjadi gubernur dan lain-lain maka Rasulullah bersabda: "ini adalah amanat berat dan engkau adalah orang yang lemah" (Kahlani, Subulus salam juz IV, 1182 H, hlm 117).

Selain penempatan yang tepat, keahlian juga merupakan hal yang sangat penting yang harus dimiliki oleh karyawan dalam suatu organisasi, bahkan dalam sebuah hadis Rasulullah saw bersabda: Apabila sebuah urusan diserahkan bukan pada ahlinya maka tunggulah saat kehancurannya (HR. Bukhari).

Makna yang dapat disimpulkan dari hadis tersebut diatas adalah: seseorang harus ditempatkan pada posisi yang tepat, sesuai dengan keahlian yang dimiliki.

\section{Jenis-Jenis Penempatan}

Jenis jenis penempatan menurut Ardhana (2012:111) adalah: a. Promosi

Promosi merupakan proses penempatan pegawai sebagai penghargaan atau hadiah atas usaha dan prestasinya di masa lampau dengan memindahkannya ke level yang lebih tinggi dari pekerjaan yang sebelumnya. 
b. Transfer (rotasi)

Transfer adalah proses menempatkan pegawai ke bidang lain yang tingkatannya hampir sama baik dari segi tanggung jawab, tingkatan struktur, maupun tingkatan gajinya.

c. Demosi

Demosi merupakan kebalikan dari promosi, dimana demosi menempatkan seseorang pegawai ke posisi lain yang tingkatannya lebih rendah baik dalam tingkatan gaji, tanggung jawab, maupun strukturnya.

\section{Tujuan Penempatan Kerja}

Menurut Ardana (2012: 82) Pada dasarnya yang menjadi tujuan dalam proses penempatan karyawan adalah:

a. Mengisi formasi atau lowongan pekerjaan yang tersedia dalam perusahaan

b. Karyawan yang baru lulus tidak terlalu lama menunggu diangkat

c. Menempatkan orang yang tepat pada posisi yang tepat

d. Agar perusahaan dapat bekerja efisien dengan memanfaatkan SDM yang tepat.

\section{Faktor- faktor yang harus diperhatikan dalam penempatan karyawan}

1. Latar Belakang Pendidikan

Faktor Latar belakang pendidikan karyawan harus menjadi pertimbangan perusahaan untuk dapat menempatkan karyawan sesuai dengan prestasi akademik yang telah dicapai, karena dengan melihat prestasi akdemik yang telah dicapai, perusahaan dapat menyesuaikan beban kerja. Karyawan dengan prestasi akademis yang tinggi harus ditempatkan pada tugas dan pekerjaan yang diperkirakan mampu dilaksanakan meskipun pekerjaan tersebut dipandang berat dan memerlukan tanggung jawab besar.

2. Kesehatan fisik dan mental

Tes kesehatan berdasarkan laporan dokter atau tes kesehatan khusus yang diselenggaran pada saat proses seleksi tenaga kerja, tidak menjamin karyawan benar-benar sehat jasmani dan rohani. Terkadang hasil pengujian tes kesehatan tidak selalu akurat, oleh karena itu perusahaan perlu berhati- hati dalam menempatkan karyawan, agar tidak terjadi masalah yang dapat merugikan perusahaan. Pekerjaanpekerjaan berat hanya dapat dilakukan oleh orang yang sehat secara fisik dan mental. Oleh karena itu, pekerjaan yang akan dilakukan harus disesuaikan dengan kondisi fisik dan mental karyawan yang bersangkutan. 


\section{Pengalaman Kerja}

Pengalaman bekerja pada pekerjaan yang sama perlu mendapatkan perhatian khusus oleh perusahaan dalam penempatan karyawan. Karyawan dengan pengalaman kerja tinggi cenderung akan memiliki keahlian dan ketrampilan tinggi dibandingkan dengan karyawan yang belum berpengalaman.

4. Faktor Status Perkawinan

Status perkawinan karyawan merupakan hal penting yang harus diketahui perusahaan. Selain untuk menjaga kepentingan karyawan, hal ini juga dapat dijadikan bahan pertimbangan bagi manajer tenaga kerja dalam melakukan penempatan.

5. Usia

Faktor usia tenaga kerja yang lulus seleksi perlu mendapat perhatian perusahaan. Hal ini untuk menghindari produktivitas karyawan yang rendah tenaga kerja yang usianya agak tua atau yang sudah pensiun sebaiknya ditempatkan pada pekerjaan yang tidak memiliki resiko dan bahaya terlalu tinggi serta tanggung jawab berat.

Menurut pendapat Ibnu Taimiyah (dalam Fahmi, 2014:92-93) metode yang digunakan oleh Rasulullah dalam penempatan karyawan yang mengelola pemerintahan adalah sebagai berikut

a. Mengangkat individu yang aslah (paling layak dan sesuai). Menurut riwayat, pada saat Rasulullah menaklukkan kota Makkah dan menerima kunci ka'bah dari Bani Syaibah, kunci tersebut diminta oleh Abbas bin Abdul Mutallib dengan tujuan agar Abbas memiliki dua tugas sekaligus yaitu: memberi minum jamaah haji (siqayah) serta pelayan ka'bah (rifadah) kemudian turun surah An-nisa ayat 58-59. Ayat tersebut di atas yang memerintahkan Rasulullah agar tetap mempercayakan kunci tersebut pada bani Syaibah. Kisah tersebut mengindikasikan adanya kewajiban untuk menempatkan individu yang paling kompeten dan layak untuk menempati jabatan tertentu agar dapat melaksanakan tugas secara efektif dan efisien. Rasulullah S.A.W bersabda: Barangsiapa mengangkat seseorang untuk mengurusi suatu perkara kaum muslimin sementara ada orang yang lebih layak dan sesuai daripada orang- orang yang diangkatnya ,maka sesungguhnya ia telah berkhianat kepada Allah dan Rasul-Nya (H.R Baihaqi)

Hadis tersebut memberi petunjuk bahwa kebijakan dalam menempatkan karyawan harus dilakukan melalui seleksi seketat mungkin hadis tersebut juga mengisyaratkan bahwa jangan sekali-kali menyerahkan suatu pekerjaan pada seseorang yang meminta jabatan.

b. Memilih individu dengan kualitas terbaik memilih dan mengangkat karyawan yang benar-benar mumpuni (memenuhi semua 
kriteria) bukan perkara mudah Apabila ditemukan calon karyawan tanpa cela harus dipilih secara selektif seseorang yang mempunyai kualitas tertinggi dari sejumlah calon yang ada

c. Memilih individu yang kafaah (kapabilitas) dan amanah. Islam mendorong umatnya untuk memilih calon karyawan berdasarkan pengetahuan, pengalaman dan kemampuan teknis yang dimiliki (Sinn,2006:108) Hal ini sesuai dengan firman Allah QS. Al-Qashash:26.

Kekuatan yang dimaksud disini dapat berbeda sesuai dengan jenis pekerjaan, kewajiban, dan tanggung jawab yang dipikulnya. Amanah merupakan faktor penting untuk menentukan kepatutan dan kelayakan seseorang calon karyawan. Hal ini bisa diartikan dengan melaksanakan segala kewajiban sesuai dengan ketentuan Allah dan takut terhadap aturannya. Selain itu melaksanakan tugas yang dijalankan dengan sebaik mungkin sesuai prosedur tidak dilandasi unsur nepotisme kedzaliman, penipuan, intimidasi, atau kecendrungan terhadap golongan tertentu.

Calon karyawan harus dipilih berdasarkan kepatutan dan kelayakan. Mengenai hal ini Rasulullah S.A.W bersabda: Barang siapa memperkerjakan orang karena ada unsur nepotisme padahal ada orang yang lebih baik daripada orang tersebut, maka ia telah mengkhianati amanah yang telah diberikan Allah, Rasul-Nya, dan kaum muslimin

Proses penempatan karyawan dalam Islam harus berdasarkan uji kepatutan dan kelayakan calon karyawan atas pekerjaan yang akan dijalaninya. Dalam kitab Al- Siyasah al-Syar'iyyah' Ibn Taimiyah menjelaskan hal terpenting dalam penempatan karyawan adalah mengetahui yang paling pantas dan layak

\section{Rotasi Kerja}

Menurut Sofyandi (2013: 117) Rotasi merupakan pelatihan karyawan yang dilakukan dengan cara memindahkan karyawan dari suatu pekerjaan ke pekerjaan lain . dengan metode ini diharapkan para peserta program dapat mengetahui dan mengerti tugas masing- masing.

\section{Tujuan Rotasi}

Menurut Kasmir (2016:167) tujuan rotasi tergantung dari beberapa hal yang

dilakukan untuk:

a. Menambah atau memperkaya pengetahuan karyawan tentang suatu pekerjaan lain sehingga kemampuan dan keahliannya ikut bertambah

b. Menghilangkan kejenuhan atas pekerjaan yang selama ini dijalankan sehingga menjadi lebih segar. 
c. Cara yang dilakukan untuk mempromosikan karyawan.

d. Merupakan tindakan pemberian hukuman ringan atas kesalahan karyawan.

\section{Tujuan Rotasi}

Menurut Wahyudi (dalam Harisman 2011: 12) tujuan rotasi adalah

a. Production transfer Adalah bentuk rotasi horizontal dengan tujuan mengisi kekosongan pekerja pada posisi jabatan tertentu yang harus segera diisi agar kontinuitas produksi dan peningkatannya dapat terjamin.

b. Versatility transfer Adalah bentuk rotasi horizontal yang bertujuan untuk menempatkan karyawan dengan kecakapan tertentu pada jabatan-jabatan yang membutuhkan kecakapan tersebut.

c. Remedial transfer Adalah pemindahan yang ditujukan untuk menempatkan karyawan pada jabatan yang sesuai dengan kondisi kerja karyawan yang bersangkutan.

\section{Kinerja}

Secara sederhana kinerja adalah tentang apa yang dikerjakan dan bagaimana cara mengerjakannya (Wibowo,2007:7). Dalam pandangan islam kinerja dianggap sebagai kesempurnaan seseorang dalam melakukan pekerjaan yang dibebankan kepadanya kesempurnaan yang dimaksud adalah jika seseorang melakukan pekerjaan secara professional yaitu melakukan yang terbaik dan lebih baik lagi setiap harinya. Hal ini sesuai dengan hadis Nabi yaitu:

Sesungguhnya Allah sangat mencintai jika seorang melakukan suatu pekerjaan yang dilakukannya dengan itqan atau sempurna (professional) (HR.Thabrani) Dari kutipan hadis tersebut diatas dapat disimpulkan bahwa ukuran kinerja seseorang dapat dilihat dari sempurnanya pekerjaan yang dilakukan dengan adanya perbaikan yang terus dilakukan.

Karena bekerja dan berusaha merupakan bagian dari beribadah maka implementasi dari bekerja perlu dilandasi dengan akhlak atau sering disebut dengan etika profesi yang tercermin dari kata SIFAT (Shiddiq, Istiqamah, Fathanah, Amanah,Tabligh) (Hafidhuddin, 2003: 4546)

Shiddiq artinya mempunyai kejujuran dan selalu melandasi ucapan, keyakinan, dana mal perbuatan atas dasar nilai-nilai yang benar berdasarkan ajaran islam. Tidak ada kontradiksi dan pertentangan yang sengaja antara ucapan dengan perbuatan atas dasar niali-nilai yang 
benar berdasarkan ajaran islam. Dalam sebuah hadis Rasulullah bersabda:

"Hendaknya kalian jujur (benar)karena kejujuran itu mengantarkan kepada kebaikan dan kebaikan akan mengantarkan kedalam surga seseorang yang selalu berusaha untuk jujur, akan dicatat oleh Allah sebagai orang yang jujur. Dan jauhilah oleh kamu sekalian kidzb (dusta) karena dusta itu akan mengantarkan kepada kejahatan. Dan kejahatan akan mengantarkan kedalam neraka . seseorang yang selalu berdusta akan dicatat oleh Allah sebagai pendusta". (HR. BUKHARI)

Dalam dunia kerja dan usaha kejujuran ditampilkan dalam bentuk kesungguhan dan ketepatan (mujahadah dan itqan), baik ketepatan waktu menepati janji, pelayanan, pelaporan, mengakui kelemahan dan kekurangan,(tidak ditutup-tutupi) kemudian diperbaiki secara terusmenerus, serta menjauhkan diri dari berbuat bohong dan menipu (baik pada diri sendiri, teman sejawat, perusahaan maupun mitra kerja)

Istiqamah artinya konsisten. Dalam iman dan nilai-nilai yang baik,meskipun menghadapi berbagai godaan dan tantangan. Istiqamah dalam kebaikan ditampilkan dalam keteguhan dan kesabaran serta keuletan sehingga menghasilkan sesuatu yang optimal. Istiqamah merupakan hasil dari proses yang dilakukan secara terus-menerus, orang dan lembaga yang istiqamah dalam kebaikan akan mendapatkan ketenangan dan sekaligus mendapatkan solusi dan jalan keluar dari segala persoalan yang ada. Hal ini sesuai dengan firman Allah (QS. fushshilat 30-31).

Fathanah artinya mengerti memahami, dan menghayati secara mendalam segala hal yang menjadi tugas dan kewajibannya . sifat ini akan menumbuhkan kreatifitas dan kemampuan melakukan inovasi yang bermanfaat. Sifat fathanah ini yang mengantarkan nabi yusuf menjadi bendaharawan mesir, sebagaimana disebutkan dalam Al-qur'an.

berkata Yusuf: "Jadikanlah aku bendaharawan negara (Mesir); Sesungguhnya aku adalah orang yang pandai menjaga, lagi berpengetahuan".(QS Yusuf:55).

Amanah artinya bertanggung jawab dalam melaksanakan setiap tugas dan kewajiban. Amanah ditampilkan dalam keterbukaan, kejujuran, pelayanan yang optimal, dan dan ihsan (berbuat yang terbaik ) dalam segala hal. Sifat amanah penting untuk dimiliki seorang muslim, khususnya bagi muslim yang berhubungan dengan pelayanan kepada masyarakat

Tablig berarti mengajak sekaligus memberikan contoh kepada pihak lain untuk melaksanakan ketentuan-ketentuan ajaran islam dalam 
kehidupan sehari-hari tablig yang disampaikan dengan hikmah ,sabar, argumentatif, dan persuasif akan menumbuhkan hubungan kemanusiaaan yang semakin solid dan kuat.(Hafidhuddin \& Tanjung,2003: 36-38)

\section{Hipotesis}

Hipotesis merupakan jawaban sementara terhadap rumusan masalah penelitian. Dikatakan sementara karena jawaban yang diberikan baru didasarkan pada teori yang relevan tetapi memungkinkan untuk diuji dalam kenyataan empiris. Hipotesis mengemukakan pernyataan tentang harapan peneliti mengenai hubungan-hubungan antar variabel di dalam persoalan. Adapun hipotesis dalam penelitian ini yaitu:

H0: Penempatan Kerja dan Rotasi Kerja tidak memiliki pengaruh positif dan signifikan terhadap kinerja karyawan

H1: Penempatan Kerja berpengaruh positif dan signifikan terhadap kinerja karyawan

H2: Rotasi Kerja berpengaruh positif dan signifikan terhadap kinerja karyawan.

H3: Penempatan Kerja dan Rotasi Kerja berpengaruh positif dan signifikan terhadap kinerja karyawan.

\section{Metodologi Penelitian}

Penelitian dilakukan dengan metode kuantitatif deskriptif statistik deskriptif, yaitu statistik yang digunakan untuk menganalisis data dengan cara mendeskripsikan/ menggambarkan data yang telah terkumpul sebagaimana adanya tanpa bermaksud membuat kesimpulan yang berlaku untuk umum atau generalisasi (Sugiyono,2015:207).

\section{Jenis Data}

Data yang digunakan dalam penelitian ini adalah data kuantitatif berupa data primer yang berasal dari angket yang disebarkan kepada sejumlah karyawan pada bank yang diteliti.

\section{Populasi dan Sampel}

Populasi dalam penelitian ini berjumlah 70 orang, akan tetapi, peneliti hanya dapat memperoleh sebagian sampel saja yang dapat digunakan. Sampel adalah sebagian jumlah dan karakteristik yang dimiliki oleh populasi tersebut (Suranto, 2009:116).

Dalam penelitian ini, peneliti mengambil sampel dengan tekhnik purposive sampling. Purposive sampling merupakan tekhnik pengambilan sampel dengan pertimbang an tertentu berdasarkan pada 
karakteristik tertentu yang dianggap mempunyai sangkut paut dengan karakteristik populasi yang sudah diketahui sebelumnya (Sugiyono, 2015:120-122).

\section{Metode Pengolahan Analisis Data}

Analisis data menggunakan model regresi linear berganda (multiple regression analysis). Model ini menguji kedua variabel dependen, baik secara individual (partial) maupun secara keseluruhan (simultan), terhadap variabel independen menggunakan SPSS 21.0.

a. Definisi Operasional Variabel

Variabel dalam penelitian ini terdiri dari satu variabel dependen dan dua variabel independen. Variabel dependen adalah kinerja karyawan, variabel independen adalah variabel Penempatan Kerja dan Rotasi Kerja .

1) Variabel Dependen: Kinerja Karyawan

Menurut Mangkunegara (2000: 9) kinerja karyawan (prestasi) adalah hasil kerja secara kualitas dan kuantitas yang dicapai oleh seorang karyawan dalam melaksanakan tugasnya sesuai dengan tanggung jawab yang diberikan kepadanya.

2) Variabel Independen

\section{Penempatan Kerja}

Penempatan kerja merupakan pengalokasian para karyawan pada posisi kerja tertentu. Penempatan karyawan merupakan pencocokan atau membandingkan kualifikasi yang dimiliki dengan persyaratan pekerjaan, dan sekaligus memberikan tugas, pekerjaan kepada calon karyawan untuk dilaksanakan.

\section{Rotasi Kerja}

Rotasi merupakan proses perpindahan karyawan dari satu jenis pekerjaan ke jenis pekerjaan lain dalam jangka waktu yang direncanakan.

b. Metode Pengolahan Data

Pengolahan data menggunakan statistik deskriptif dengan persamaan Uji Regresi Linear Berganda untuk menguji hipotesis dengan persamaan berikut:

$Y=\alpha+\beta 1$ penempatan kerja $+\beta 2$ Rotasi kerja $+\varepsilon$ 
Di mana:

$\mathrm{Y}=$ Variabel kinerja

$\alpha=$ Konstanta

$\beta 1=$ Variabel Penempatan kerja $\beta 2=$ Variabel Rotasi kerja

$\varepsilon=$ error

Uji Statistik yang dilakukan meliputi Uji Normalitas, Uji Multikolinearitas,Uji Autokorelasi, Uji Heteroskedastisitas, Uji Hipotesis, Uji Statistik T dan Uji Signifikasi Simultan (Uji F).

\section{Hasil dan Pembahasan}

Dilihat dari 30 sampel penelitian, diketahui ukuran pemusatan variable penempatan kerja dengan nilai range: 30 , nilai minimum: 23 , nilai maksimum: 46, nilai rata-rata: 38,02. Sedangkan untuk nilai ukuran penyebaran yang terdiri dari standar deviasi: 5,483, dan nilai varian: 30,06 . Ukuran pemusatan variabel rotasi kerja dengan nilai range: 69,28 , nilai minimum: 47, nilai maksimum: 98 nilai rata-rata: 69,28 sedangkan untuk nilai penyebaran standar deviasi: 247 , dan nilai varian: 85,50. Ukuran pemusatan variabel kinerja dengan nilai range: 58, nilai minimum: 62 , nilai maksimum: 120 , nilai rata-rata: 89,02 , sedangkan untuk nilai penyebaran standar deviasi: 11,26, dan nilai varian: 126,7.

Pada uji normalitas, dapat disimpulkan bahwa data penelitian berdistribusi normal, yang ditandai dengan bentuk kurva yang memiliki kemiringan seimbang pada sisi kiri dan kanan. Uji Autokorelasi Durbin watson hitung mendekati angka 2. Durbin Watson hitung adalah 1,725, mendekati angka 2, maka dapat disimpulkan pada analisis regresi penelitian ini tidak terdapat autokorelasi.

Uji multikolinearitas menghasilkan nilai VIF untuk variabel X1 dan $\mathrm{X} 2$ dengan nilai yang sama besarnya dibawah 10 . Pada variabel $\mathrm{X} 1=$ 1,220 dan $X 2=1,220$. Nilai ini berarti kurang dari sepuluh. Hal ini menunjukkan bahwa tidak terjadi multikolinearitas yang tinggi antar variabel bebas dalam persamaan regresi yang diperoleh. Uji heteroskedastisitas menunjukkan bahwa titik-titik tidak membentuk pola khusus, atau data bersifat homogen.

Hasil dari analisis data secara garis besar adalah sebagai berikut: nilai konstanta adalah 6,462. Artinya, ketika tidak ada tambahan dari Penempatan kerja dan Rotasi kerja maka Kinerjanya adalah 6,462. Apabila adanya tambahan sebesar satu satuan dari variabel penempatan kerja, maka kinerja berkurang sebesar 0,27. Apabila ada tambahan sebesar satu satuan dari variabel rotasi kerja maka kinerja bertambah sebesar 1,206. 
Nilai t hitung adalah $-0,358$ dengan $\mathrm{p}$-value 0,72 sedangkan nilai $\mathrm{t}$ tabel sebesar 1,701 ini berarti -0,358>0,05 tidak signifikan dengan nilai t hitung lebih kecil daripada t tabel $=-0,358<1,701$. Dengan demikian dapat disimpulkan bahwa variabel X1 pada level 95\% $(\alpha=5 \%)$, maka Ho diterima dan Ha ditolak. Hasil uji individu ini membuktikan bahwa secara parsial tidak ada hubungan atau pengaruh positif secara individu variabel penempatan kerja dengan kinerja karyawan. Secara individu variabel penempatan kerja tidak berpengaruh terhadap peningkatan kinerja karyawan. Hal yang sama dilakukan untuk mengetahui pengaruh secara individual pada variabel rotasi kerja (X2) uji t pada tabel menunjukkan nilai t hitung adalah 27,179 dengan p-value 0,00 sedangkan nilai t tabel sebesar 1,701 ini berarti 27,179>0,05 tidak signifikan dengan nilai $t$ hitung lebih besar daripada $t$ tabel $=27,179>1,701$.Dengan demikian dapat disimpulkan bahwa variabel X2 pada level 95\% ( $\alpha=5 \%)$ maka Ho ditolak dan Ha diterima. Hasil uji individu ini membuktikan bahwa secara parsial terdapat pengaruh signifikan antara variabel Rotasi kerja dengan kinerja karyawan.

Uji F menunjukkan apakah variabel independen yang dimasukkan dalam model mempunyai pengaruh terhadap variabel dependen. Penempatan Kerja (X1) dengan variabel Rotasi Kerja secara bersamasama terhadap variabel dependen $(Y)$ dengan hasil perhitungan $F$ test yang menunjukkan nilai: 445,52 dengan tingkat probabilitas 0,000 yang jauh dibawah alpha 5\% . Hal ini berarti bahwa Fhitung $>$ Ftabel . Dengan nilai koefisien determinasi (R2) adalah 0,971, yang artinya bahwa variabel-variabel independen yaitu variabel Penempatan Kerja dan Rotasi Kerja mempengaruhi variabel dependen yaitu Kinerja Karyawan sebesar 97,1\%, sedangkan 2,9\% dipengaruhi variabel lain yang tidak diteliti dalam penelitian ini.

\section{Kesimpulan}

Secara keseluruhan, penelitian ini menunjukkan bahwa variable penempatan kerja dan rotasi kerja jika dilakukan bersamaan, berpengaruh positif terhadap kinerja karyawan. 